\title{
MANISSA'DA ÂYÂN SOYUNDAN SON İDARECİ: SARUHAN KAYMAKAMI MEHMED SADIK BEY
}

\author{
Ferhat BERBER ${ }^{1}$
}

\begin{abstract}
ÖZ
Karaosmanoğlu ailesi 18. yüzyllın ortalarından 19. yüzyılın ilk çeyreğine kadar Batı Anadolu'nun en güçlü âyân ailesiydi. 19. yüzyılın başlarından itibaren âyânlar zayıfladı ve taşra idaresindeki etkileri giderek azaldı. Tanzimat ile birlikte taşra idaresinde merkezden atanan memurlar görev yapmaya başlamışlardır. Bu çalışmada Karaosmanoğlu ailesine mensup Mehmed Sadık Bey'in Saruhan Sancağı Kaymakamliğı ele alınmıștır. Sadık Bey bu aileden çıkan son idarecidir.

Anahtar Kelimeler: Osmanl, Saruhan, Manisa, Karaosmanoğlu, Mehmed Sadık Bey.

\section{THE LATEST ADMINISTRATOR DESCENDING FROM LOCAL NOTABLES IN MANISA PROVINCE: MEHMET SADIK BEY, THE DISTRICT GOVERNOR OF SARUHAN}

\begin{abstract}
Karaosmanoğlu Family was the most powerful notable family from the middle of the 18th century to the first quarter of the 19th century. The Ottoman notables had started losing power at the beginning of the 19th century and their influence on the provincial administration had gradually declined. Following the launch of Tanzimat, officers assigned from the central administration began to work in the countryside. This article discusses the district governorship of Mehmed Sadık Bey, from Karaosmanoğlu Family, of the Saruhan Sandjak. Mehmed Sadık Bey is the last governor descending from this family.
\end{abstract} Sadık Bey.

Keywords: Osmanl, Saruhan, Manisa, Karaosmanoğlu, Mehmed

1Yrd. Doç. Dr., Celal Bayar Üniversitesi, Fen-Edebiyat Fakültesi, Tarih Bölümü, ferhat_berber@yahoo.com. 


\section{I.Giriş}

Karaosmanoğlu ailesi 18. yüzyılın ortalarından itibaren güçlenerek yüzyılın sonlarında Manisa merkez olmak üzere Batı Anadolu'nun en kudretli âyân ailesi haline gelmiştir. Aile fertleri Manisa, Aydın ve İzmir çevresinde muhassıl, mütesellim ve voyvoda sıfatları ile çeșitli bölgelerin yönetimini ellerine almıșlardır. Özellikle Manisa çevresinde pek çok toprağı kendi mülklerine dönüştürmüşlerdir. Bundan başka ailenin ticari ilişkileri çerçevesinde bilhassa İzmir'de çeşitli mülkler edindiği de görülmektedir. Osmanlı araştırmaları literatüründe mütegallibe olarak nitelenen bu ailenin devletle ilişkileri kimi zaman olumlu seyretse de kimi zaman aile fertlerinden bazıları devlet tarafından ortadan kaldırılmıştır. Bölge ahalisi ile ilişkilerinin ise otoriter bir yönetim etrafında geliştiği söylenebilir. ${ }^{2}$

Sultan II. Mahmud döneminden itibaren devlet teşkilatında meydana gelen merkezileşme çalışmaları âyanların güçlerini kaybetmesinde en önemli etken olmuştur. Bu çerçevede idari taksimatta çeşitli değişliklere gidilmiş, yerel yönetim birimlerinin başına standart vasıflarla merkezce onaylanan idareciler getirilmiştir. Akabinde Tanzimat reformları çerçevesinde bu düzenlemeler devam etmiş zamanla merkezi idarenin devlet yönetiminde âyân ve eşraftan yararlanma biçimi minimum seviyeye indirilmiștir. $^{3}$

Bu çerçevede Saruhan Sancağı, 1833'te Aydın Vilayeti'ne bağlanmıș, 1845 yılında Aydın'dan ayrılarak yine Hüdavendigar Vilayeti'nden ayrılan Karesi Sancağı ile birleştirilip ayrı bir birim haline getirilmiş, 1847 yllında ise yeniden Aydın Vilayeti'ne bağlanmıștır. ${ }^{4}$

${ }^{2}$ Yuzo Nagata, Tarihte Âyânlar Karaosmanoğulları Üzerinde Bir İnceleme, TTK, Ankara 1997, isimli çalışmasında aileyi ayrıntıları ve örnekleriyle etraflıca incelemiştir.

${ }^{3}$ Konunun ayrıntıları için bkz. Musa Çadırcı, Tanzimat Döneminde Anadolu Kentlerinin Sosyal ve Ekonomik Yapısl, TTK Ankara, 1997 ve aynı yazar, Tanzimat Sürecinde Türkiye Ülke Yönetimi, İmge Kitabevi, Ankara 2007

"Feridun Emecen, "Manisa", TDVIA, http://www.islamansiklopedisi.info/dia/pdf/c27/c270394.pdf

s.

582 , (erişim: 10.08.2015);

Bilindiği üzere klasik dönem Osmanlı tașra teșkilatında en üst birim eyalet/beylerbeyilik olup bunlar da bugünkü iller büyüklüğündeki sancaklardan oluşmaktaydı. Ancak 18. yüzyılda ortaya çıkan âyânlık döneminde taşra idaresinde merkezin kontrolü sağlayamadığı bilinmektedir. II. Mahmud döneminde önceki dönemden farklı olarak mülki taksimat askeri gerekçelerle farklı bir şekilde düzenlenmeye çalışıldı. Bu çerçevede 19. yüzyıl boyunca varlığını devam ettirecek olan Aydın Vilayeti'nin de temelleri atıldı. Aydın Redif Müșirliği; Aydın, Saruhan, Sığla ve Menteșe sancaklarından olușup başına da Aydın muhassılı Karaosmanoğlu

292 | Celal Bayar Üniversitesi Sosyal Bilimler Dergisi - Cilt: 13, Sayı: 3, Eylül 2015 
$\mathrm{Bu}$ çalışmanın konusu Karaosmanoğlu ailesinden Hacı Mehmed Sadık Bey'dir. En meşhur âyân ailelerinden birine mensup olmakla birlikte Tanzimat döneminin başlarında Saruhan Sancağı kaymakamlığ $1^{5}$ yapan Sadık Bey geçiş döneminin en önemli örneklerinden birisidir.

\section{Ailesi}

Babası Hacı Eyüp Ağa'dır. 1833 yılında Manisa mütesellimi olmuş, 1835 yılında Mir-i Ahur-1 evvel payesi almış 1837'de mütesellimlik görevinden alınmış, 1839 'da muhassıllıkla görevlendirilmiş, 1842 yılında Aydın kaymakamı olmuştur. Uluçay, Manisa Ünlüleri; Nagata da, Tarihte Âyânlar isimli eserlerinde Mehmed Sadık Bey'in babası Hacı Eyüp Ağa'nın 1845 yılında Manisa'da öldüğünü bildirmektedirler. ${ }^{6}$ Ancak aynı yazarın İbrahim Gökçen ile birlikte hazırladığı Manisa Tarihi isimli eserde Lütfi Tarihi'ne dayandırılarak ölüm tarihi 1854 olarak verilmektedir. ${ }^{7}$

Hacı Eyüp Ağa'nın ilerleyen yaşlarında oğlunun himayesinde bulunduğunu söylemek gerekir. 1844 tarihinde Mehmed Sadık Bey Saruhan Kaymakamlığı görevini yürütmekte iken Beyrut'ta ikamet

Yakup Paşa getirildi. Çadırcı, Ülke Yönetimi, s. 116; Bundan sonraki süreçte Aydın Vilayeti farklı taksimatlarla düzenlense de hemen hemen bugünkü Ege Bölgesini kapsayacak büyüklükteki varlığını devam ettirdi. Zaman zaman değişmekle birlikte genellikle vilayeti olușturan sancaklar şu şekildeydi: İzmir, Aydın, Saruhan (Manisa), Menteșe (Muğla), Denizli. Bkz. Tuncer Baykara, Anadolu'nun Tarihi Coğrafyasına Giriş I Anadolu'nun İdari Taksimatı, Türk Kültürünü Araștırma Enstitüsü, Ankara 2000, s. 226-228; Saruhan Sancağı ise kimi zaman havi olduğu kazalar değişmekle birlikte, neredeyse bugünkü Manisa Vilayeti büyüklüğünde bir idari birim olarak varlığını devam ettirdi. Saruhan Sancağı'nın idari taksimatı için bkz. Nejdet Bilgi, “Tanzimat'ın Öncesi ve Sonrasında Saruhan Sancağı'nda Nüfus", Prof. Dr. İsmail Aka Armağanı, Yay. Haz. N. Bilgi, M. Ersan v.d., İzmir 1999, ss. 249-290.

Gerek Aydın Vilayeti gerekse Saruhan Sancağı'nın 19. yüzyılın ikinci yarısından 20. yüzyılın başlarına kadar geçirdiği mülki taksimat değişimleri için Aydın Vilayet Salnamelerine bakılmalıdır.

${ }^{5}$ Kaymakam, Osmanlı devlet teşkilatında saray hizmetleri, mülki idare ve askeri hiyerarşide genellikle vekil idareciler için kullanılan bir terimdir. Tanzimat ile birlikte sancak yöneticileri Kaymakam olarak adlandırıldı. 1864 Vilayet Nizamnamesinden sonra ise Sancakların başında yöneticiler Mutasarrıf olarak isimlendirilirken, kaza idarecilerine kaymakam unvanı verildi. Yücel Özkaya, "Kaymakam", TDVIA, http://www.islamansiklopedisi.info/dia/pdf/c25/c250059.pdf (erişim: 06.08.2015) Yani Mehmed Sadık Bey bugünkü Manisa Vilayeti büyüklüğünde olan Saruhan Sancağını idare etmekle, günümüzdeki Vali'nin karşılığı olan bir görevi icra etmiști.

6 M. Çağatay Uluçay, Manisa Ünlüleri, Manisa Lisesi Yayını, Manisa 1946, s. 60-61; Nagata, a.g.e. s, 314

7 Çağatay Uluçay-İbrahim Gökçen, Manisa Tarihi, Manisa Halkevi Yayını, Resimli Ay Matbaası, İstanbul 1939, s. 57 ve Ahmed Lûtfî Efendi, Vak'anüvîs Ahmed Lûtfî Efendi Tarihi, C. 6-7-8,Türkiye Ekonomik ve Toplumsal Tarih Vakfı-Yapı Kredi Yayınları, ed. Nuri Akbayar, İstanbul 1999, s. 1185 


\section{Ferhat Berber}

etmekte olan babasının, oranın havası ile uyuşamadığını, bir müddet Manisa'da ikamet etmesi için izin istediğini görmekteyiz. ${ }^{8}$

Amcası Yakup Paşa ise 1826-1854 yılları arasında çok önemli görevlerde bulunmuş bir devlet adamı konumundadır. Vezir rütbeli Yakup Paşa Aydın, Edirne, Rumeli, Selanik, Kudüs valiliklerinde bulunmuş, 1854 yılında ölmüştür. ${ }^{9}$

Sadık Bey'in üç zevcesi olduğu görülmektedir. İlki Ayşe Hanım bint Ahmed Ağa'dır. Diğer iki zevcesinin isimleri ise, Canfeza Kadın bint Abdullah ve Aşk-ı Niyaz Kadın bint Abdullah'tır. Bu iki zevcesinin baba isimleri, gayrimüslim olabileceklerini akla getirmektedir. Tek başına bunun yeterli olduğu söylenemez. Ancak aşağıda görüleceği üzere Sadık Bey'in tereke paylaşımında Ayşe Hanım Manisa'da bulunan ve Müslümanlar tarafından işletilen dükkânları alırken, İzmir'de bulunan Rumhanelerin ve Rumların işlettiği dükkânların tamamının diğer iki zevcesinin üzerine verilmesi de bu fikri kuvvetlendirmektedir. ${ }^{10}$

Sadık Bey'in Ayşe Hanım'dan olma11 tek oğlu Arif Bey, Divan-ı Hümayun Hocalığı payesine sahiptir. ${ }^{12}$ Canfeza Kadın'dan ise Cemile ve Hatice isminde iki kızı bulunmaktadır. ${ }^{13}$

Nagata'nın düzenlediği aile şeceresinden ${ }^{14}$ hareketle Mehmed Sadık Bey'in şeceresi şu şekildedir:

\begin{tabular}{|l|c|}
\hline İsim & $\begin{array}{c}\text { Ölüm } \\
\text { Tarihi }\end{array}$ \\
\hline Mehmed Çavuş (ailenin atası) & 1644 \\
\hline Kara Osman (ailenin isim babası) & 1706 \\
\hline Mustafa & 1755 \\
\hline Pulad Mehmed Ağa & 1806 \\
\hline Hacı Eyüp Ağa & 1845 \\
\hline Hacı Mehmed Sadık Bey & 1861 \\
\hline Mehmed Arif Bey (oğlu) & \\
\hline Cemile Hanım (kızı) & \\
\hline Hatice Hanım (kızı) & \\
\hline
\end{tabular}

\footnotetext{
8 BOA. A.MKT. $12 / 241260$ 4. 23. (12 Mayıs 1844)

9 Uluçay, Manisa Ünlüleri, s. 61; Uluçay burada Yakup Kadri Karaosmanoğlu'nun da adı geçen Yakup Paşa'nın ailesinden olduğunu belirtmektedir.

10316 numaralı MŞS; Nagata zevcelerinin ismini Canfeda ve Aşk-ınaz olarak okumuștur. Nagata, a.g.e., s 314

11316 numaralı MŞS ve Nagata a.g.e., s. 314

12 BOA. A. MKT. UM. 9/10 1266 4. 13. (26 Şubat 1850)

13316 numaralı MŞS

14 Nagata, a.g.e., s. 312-315
}

294 | Celal Bayar Üniversitesi Sosyal Bilimler Dergisi - Cilt: 13, Sayı: 3, Eylül 2015 


\section{Saruhan Kaymakamlığı Görevleri}

1842 yılında yapılan idari düzenleme ile Mehmed Sadık Bey ${ }^{15}$ Saruhan Sancağı kaymakamlığına atandı. ${ }^{16}$

Tanzimat'tan sonra kurulan Zaptiye teşkilatı çerçevesinde mülki idare birimlerinde amire bağlı olarak kolluk kuvvetleri görev yapmaya başlamıştı. M. Sadık Bey de bu çerçevede bölgede resmi olarak verilenden daha fazla zaptiye görevlendirmiști. ${ }^{17}$ Sadık Bey'in ilk kaymakamlı̆̆ı Tanzimat reformlarının uygulanmaya başlandığı ve Temettuat sayımının da yapıldığı bir döneme rastlamaktadır.

İlk kaymakamlığı yaklaşık üç yıl sürdü. 1845 yılında Saruhan Sancağı Aydın eyaletinden ayrıldı, yine Hüdavendigar eyaletinden ayrılan Karesi sancağı ile birleştirilerek yeni bir eyalet teşkil edildi. Bu çerçevede Sadık Bey'in amcası Yakup Paşa Aydın eyaleti müşirliği görevinden alınınca Sadık Bey'in de görevi son buldu. Manisa merkezli yeni eyaletin başına İbrahim Saip Paşa vali olarak atandı. ${ }^{18}$ $\mathrm{Bu}$ aziller akla Sadık Bey'in amcası Yakup Paşa'nın himayesinde olduğu izlenimine yol açmaktadır.

Sadık Bey'in 1846 yılında Saruhan Sancak Meclisi azası olması, kaymakam olmadığı dönemde de sancağın idaresi içinde bir şekilde yer aldığını göstermektedir. ${ }^{19}$

1847 Haziran'ında Saruhan Sancağı yine Aydın eyaletine dâhil edilerek başına yeniden Yakup Paşa getirildi. Bununla birlikte Saruhan Sancağı kaymakamlığı da tekrar Sadık Bey'e verildi..20 Bu görevi esnasında, daha önceki kaymakamlığında istihdam ettiği, ilave kolluk kuvvetlerinin görevde kalması ve maaşlarının mal sandığından ödenmesi merkez tarafından da onandı. Bölgedeki eşkıyalık hareketlerinin çokluğuna binaen Manisa ve kazalarının çoğunun posta yolu üzerinde olması sebebiyle bu ilave güvenlik tedbiri uygulanmaya başladı. ${ }^{21}$

\footnotetext{
15 Sadık Bey'in idari görevleri hakkındaki bilgiler, Başbakanlık Osmanlı Arşivi belgeleri ve dipnotlarda gösterilen araştırma eserlere dayanmaktadır. Mehmed Sadık Bey hakkında BOA. Sicill-i Ahval kayıtlarında, Mehmed Süreyya, Sicill-i Osmani (6 cilt), Haz. Nuri Akbayar, Tarih Vakfı Yurt Yayınları, İstanbul 1996 ve Mehmet Zeki Pakalın, Sicill-i Osmanî Zeyli (19 cilt), Haz. Heyet, TTK, Ankara 2008, isimli eserlerde de bilgi bulunmamaktadır.

16 Hilal Ortaç, Tanzimattan Birinci Meşrutiyete Manisa, Ege Üniversitesi SBE Tarih ABD, Yayınlanmamış Doktora Tezi, İzmir 1996, s. 52; Yuzo Nagata, "Karaosmanoğulları", $\quad$ TDVIA, $\quad$ s. 469 http://www.islamansiklopedisi.info/dia/pdf/c24/c240290.pdf (erişim: 09.08.2015); Nagata, Tarihte Âyânlar..., s. 56.

17 Ortaç, a.g.t. s. 77; BOA. A. MKT. 87/20 13 B 1263 (27 Haziran 1847)

18 Ortaç, a.g.t., s. 52

19 BOA. A. MKT. 54/73 22 Za 1262 (11 Kasım 1846)

20 Ortaç, a.g.t., s. 53; BOA. A.MKT. 84/94-A 1263 6. 25. (10 Haziran 1847)

21 Ortaç, a.g.t. s. 77; BOA. A. MKT. 87/20 13 B 1263 (27 Haziran 1847)
} 
1847 yılında Sadık Bey'in Sadrazam ile aralarının açık olduğu söylenebilir. Zira konu üzerine elde edilen tek belgede Sadık Bey'in Sadrazama bağlılı̆̆ını bildirip affedilmek istediği görülmektedir. Ayrıntı içermeyen söz konusu yazışmadan anlaşıldığı kadarıyla Sadrazamın Sadık Bey'e sitemi söz konusu olup Sadık Bey de bu konudaki kusurunu kabul edip af dilemektedir. ${ }^{22}$

$\mathrm{Bu}$ dönemde Tersane-i Amire'de çalışmak üzere Hıristiyan tebaadan kişilerin seçildiği bölgelerden birisinin de Saruhan'dır. Merkezden gönderilen uyarıda bu seçimin usulüne uygun olarak yapılması uyarısına riayet edileceği Sadık Bey tarafından bildirilmiștir. ${ }^{23}$

1848 yılında Sadık Bey, sağlığını gerekçe göstererek görevinden ayrıldı. ${ }^{24}$ Kaymakam olmadığı dönemlerde dahi Sadık Bey'in bölgenin ekonomik hayatında önemli bir yeri olduğu aşikârdır. Mal varlığının yanı sıra iktisadi ilișkilerde sözü geçen bir kişidir. Meselâ bir borçlu borcuna karşılık 50.000 kuruşluk elması kefaleten alacaklıya bırakmıştır. Söz konusu borçlu borcunu ödeyemeden ölmüştür. Alacaklı, aralarındaki mukaveleye dayanarak elmasları satmak üzere iken eski kaymakam Sadık Bey bu satışa engel olmuş ve elmaslara el koymuştur. Buna karşıllı Dâhiliye Vekâleti'nden kaymakama gönderilen emirnamede meselenin güzellikle ve șer'i mahkemede çözülmesi ifade edilmiștir. ${ }^{25}$

Sadık Bey'in azlinden sonra sırayla Said Efendi ve Âlim Ağa sancağın başına geldiyse de, idarede istenen verimin alınamaması sebebiyle, bölgeyi çok iyi bilen Mehmed Sadık Bey, Haziran-Temmuz 1852 'de bir defa daha Saruhan Sancağı kaymakamlığına getirildi. ${ }^{26}$

İki ylllı bu görevinin sona ermesi ise merkezin emrine uymaması sonucunda gerçekleşti. 1854 ve 1855 yıllarında İzmir ve Manisa çevresinin en mühim sorunlarından birisi zahire meselesi olmuştur. Bir taraftan Kırım Savaşı devam etmekte ve ordunun (müttefikler de dâhil) gıda ihtiyacı karşlanmak zorunda iken, aşar iltizamında görülen ihtikâr hareketleri sebebiyle zahire alım-satımı yasaklanmıştır. Akabinde vuku bulan çekirge istilasının sorunu daha

\footnotetext{
22 B0A. A.MKT. 78/27 07 Ca. 1263 (23 Nisan 1847) Söz konusu sadrazam Mustafa Reşid Paşa olmalıdır. Zira 1846-1848 tarihleri arasında ilk sadaretini icra etmektedir. Kemal Beydilli "Mustafa Reşid Paşa", TDViA, http://www.islamansiklopedisi.info/dia/pdf/c31/c310228.pdf (erişim: 13.08.2015) 23 BOA. A.MKT. 94/16 1263 9. 21. (2 Eylül 1847)

24 Ortaç, a.g.t., s. 53; Mehmed Sadık Bey'in en azından 1848 yılının Haziran ayının ilk günlerine kadar kaymakamlık makamında bulunduğu bir yazışmada bu sıfatla anılmasından anlaşılmaktadır. Bkz. BOA. A. MKT. 133/3 5 B 1264 (7 Haziran 1848)

25 BOA. A.MKT 185/61 02 Ca. 1265 (26 Mart 1849)

26 Ortaç, a.g.t., s. 53-54; BOA. A. MKT. MVL. 54/71 15 L 1268 (2 Ağustos 1852); A. MKT. NZD. 57/84 7 Za. 1268 (23 Ağustos 1852)
}

296 | Celal Bayar Üniversitesi Sosyal Bilimler Dergisi - Cilt: 13, Sayı: 3, Eylül 2015 
da büyütmesine ve kitllk derecesine getirmesiyle birlikte yasak kaldırılmıştır. Bu esnada İzmir'e diğer bölgelerden zahire ulaşana kadar gerekli miktarın Manisa'dan nakledilmesi gündeme gelmiştir. Ancak Saruhan kaymakamı Mehmed Sadık Bey zahirenin İzmir'e nakline izin vermeyince Meclis-i Vala'ya kadar akseden mesele Sadık Bey'in azli ile neticelenmiştir. ${ }^{27}$

Yerine eski Duhan gümrükçüsü Aziz Efendi tayin edildi.28 Bundan sonra Siroz eski kaymakamı Vehbi Efendi göreve getirildi (1856). ${ }^{29}$ Onun ardından da İşkodra eski mutasarrıfı Rumeli Beylerbeyi payeli Atâ Paşa Saruhan Sancağı kaymakamlığına atandı (1857). ${ }^{30}$

Mehmed Sadık Bey'in Saruhan kaymakamlığına son kez tayini 1858'de Atâ Mustafa Paşa'nın azliyle gerçekleşti. ${ }^{31}$ Sadık Bey'in son kez kaymakamlık yaptığı bu dönemde Saruhan Sancağının en önemli meselelerinden birisi Kırım ve Kafkasya taraflarından gelen muhacirlerin iskânı olmuştur. Bu dönemde Rus baskısından kaçarak Osmanlı Devleti'ne sığınan Kuzey Müslümanlarının, bölgedeki yerleşimlerinin başarıyla gerçekleştirildiğini söylemek mümkündür. Ancak bu faaliyetler 1860 'lı yllar boyunca devam etse de bu sürecin ancak ilk zamanlarında Sadık Bey etkili olabilmiștir. ${ }^{32}$ Zira Mehmed Sadık Bey 1861 yılında vefat etmiştir. Saruhan Kaymakamlığı görevine ise Mehmet İzzet Bey getirilmiştir. ${ }^{33}$

\footnotetext{
27 Hilal Ortaç Gürpınarlı, "İzmir ve Saruhan Sancaklarındaki Âşar Yolsuzluğu, Kıtlık ve İdari Sonuçları”, TiD, C. XVII S. 1 Temmuz 2002, ss. 13-38;

Söz konusu hadise esnasında ihtikâr suçlaması sebebiyle görevden alınan Sadık Bey'in bir yıl sonra meydana gelen çekirge istilası ve salgından kaynaklanan kıtlık sürecinde, kaymakamlık görevinde bulunmamasına rağmen, bölgenin bazı ileri gelenleri ile birlikte piyasaya buğday ve arpa çıararak halkın ihtiyacını karşıladıkları görülmektedir. Ortaç a.g.t. s. 54

28 BOA. A. MKT. 16/100 18 R 1270 (18 Ocak 1854); İ. MVL. 321/13641 27 Ra 1271 18 Aralık 1854; A. MKT. MVL. 70/28 14 R 1271 (4 Ocak 1855); A. MKT. NZD. 126/67 18 R 1271 (8 Ocak 1855)

${ }^{29}$ A. TŞF. 21/90 22 Ca 1272 (30 Ocak 1856); A. MKT. NZD. 176/30 18 R 12722 Ca 1272 (30 Ocak 1856); İ. MVL. 357/15660 25 Za 1272 (28 Temmuz 1856); A. MKT. MVL. 81/30 18 Z 1272 (20 Ağustos 1856)

30 BOA. A. DVN. 122/84; 20 \$ 1273 (15 Nisan 1857); A. MKT. MVL. 86/76 25 \$ 1273 (20 Nisan 1857); A. MKT. NZD. 223/40 23 N 1273 (17 Mayıs 1857); A. MKT. NZD. 224/8 7 L 1273 (31 Mayis 1857)

31 Ortaç, a.g.t., s. 54-55; BOA. A. MKT. MVL. 99/13 17 Z 127429 Temmuz 1858; A. MKT. NZD. 260/71 21 Z 1274 (2 Ağustos 1858); M. Sadık Bey, yeni görevine başlaması üzerine 8 Ağustos 1858'de şükranlarını ve bağlılığını merkeze arz etmiştir. BOA. AMKT. UM. 320/74 27 Z 1274 (8 Ağustos 1858)

32 Ferhat Berber, Imparatorluktan Cumhuriyete Manisa ve Göçler (1860-1960), Hacettepe Üniversitesi SBE Yayınlanmamıș Doktora Tezi, Ankara 2010, s. 34-62

33 BOA. C. DH. 130/6465 9 C 1278 (12 Aralık 1861); A. MKT. MVL. 137/75 13 C 1278 (16 Aralık 1861); A. MKT. UM. 544/21 27 Ş 1278 (27 Şubat 1862)
} 
II. Mahmud dönemine kadar taşrada merkezin otoritesi ile ters orantılı olarak âyânların güçlenmesi ve Sadık Bey'in de Batı Anadolu'nun en kudretli âyân ailesi olan Karaosmanoğullarına mensubiyeti, üzerinde biraz düşünmeyi gerektirir. Tanzimat dönemi ile birlikte artık devletin taşra idaresinde merkezden gönderdiği temsilcilerini kullandığı bilinmekte ve bu durumun Saruhan için de geçerli olduğu yukarıda görülen atamalardan anlaşılmaktadır. Oysa burada bölge değil kişi esas alındığında Sadık Bey'in bir memurdan çok bir âyâna benzediği söylenebilir. Nitekim Mehmed Sadık Bey'in terekesinde görülen serveti ve Manisa'daki iktisadi ilişkilerin önemli bir bölümünün onun etrafında şekillenmiş olması bunun bir göstergesidir. Üstelik Sadık Bey'in Saruhan Sancağı kaymakamlığından başka hiçbir resmi görevde bulunmaması, arada atanan diğer kaymakamların görevden alınmasının ardından yine görevin ona tevcih edilmesi de bunun en önemli delilidir.

Bir başka örnek de, Sadık Bey'in konağıdır. Ölümünden sonra tereke kaydında görüldüğü üzere konağın teşrifatından ${ }^{34}$ bazı çıkarımlar yapılabilir. Oğluna devredilen konak ve eşyası buranın mamur bir hükümet konağı olduğunu göstermektedir. Sarı Oda, Yaldızlı Oda, Mabeyn Odası, Yeşil Mabeyn Odası, Meclis Odası, Zabt-ı Dava Odası ve İstintak Odası gibi bölümlerinin bulunması, buranın başlı başına bir hükümet merkezi görevini icra ettiğini göstermektedir. Saruhan Sancağı'nın idare merkezi olarak bir hükümet konağının varlığını, 1845 yılındaki Saruhan ve Karesi sancaklarının birleşimine kadar götürmek mümkün ${ }^{35}$ iken 1861 yılında ölen Sadık Bey'in bu tarihte bile kendi konağını kullanıyor olması yukarıdaki yorumları haklı çıkaracak bir bilgidir. Ayrıca, istintak (sorgu) odasının dahi Sadık Bey'in şahsi konağında yer alması, bölgedeki otoritesinin bir işareti olarak düşünülmelidir.

Hülasa resmi yazışmalarda kullandığı üsluba, merkez idarecilerine karşı olan yaklaşımına ${ }^{36}$ bakıldığında merkezin otoritesini kabullenmiş sıradan bir devlet memuru görüntüsü ortaya çıkmaktadır. Hâlbuki diğer bilgilerden hareketle, merkeze karşı var olan bu görüntüsünün yanında, Sadık Bey için belki klasik tipte bir âyân diyemesek de, en azından mütegallibe nitelendirmesini yapmak mümkündür.

\footnotetext{
34316 numaralı MŞS

35 Ortaç, a.g.t., s. 40

36 BOA. A. MKT. 84/4 19 C 1263; A. TŞF. 4/63 13 C 1264; A. TŞF. 14/34 15 M 1269;

A. TŞF. 22/6 09 C 1272; A.MKT. UM. 320/74 27 Z 1274
}

298 | Celal Bayar Üniversitesi Sosyal Bilimler Dergisi - Cilt: 13, Sayı: 3, Eylül 2015 


\section{IV. Şöhreti, Rütbe ve Nișanları}

Sadık Bey kaymakamlık görevinden önce, 16 Nisan 1836 tarihinde Kapıcıbaşılık ${ }^{37}$ rütbesi almıştır. ${ }^{38}$ Ancak bu rütbeyi hangi sebepten aldığı bilinmemektedir. Babası Eyüp Ağa'nın devlete olan hizmetlerinden dolayı sahip olduğu Istabl-ı Amire ${ }^{39}$ rütbesi Kaymakam olduktan sonra oğlu Mehmed Sadık Bey'e verilmiştir.40 Ölümüne yakın bir dönemde de kendisine dördüncü rütbeden Mecidiye Nişanı ${ }^{41}$ verilmiştir. ${ }^{42}$ Ayrıca bazı belgelerde Mehmed Sadık Bey'den "Hacı" unvaniyla bahsedilmektedir. ${ }^{43}$

Sadık Bey'in nasıl bir şöhrete sahip olduğunu tespit edebilecek kadar bilgiye sahip olmasak da Lûtfî Tarihi'nde kendisi hakkında geçen ifadeler incelenmeye değerdir. Ahmed Lûtfî Efendi şu bilgilere yer vermektedir:

Mağnisa hanedân-ı kadiminden Karaosmânzade Hacı Eyyûb Ağa bu def'a vefât eyledi. Mûmaileyhin Saruhan Sancağı kaimmakamı bulunan mahdumu Sadık Bey'in meșhûd olan hüsn-i hidmetine mebni pederinden münhâl olan nişân ile ıstabl-ı âmire rütbesi mîr-i mumaileyhe verilmişdir...

Vaktiyle bu ıstabl-ı âmire rütbesi âdetâ vezârete yakın bir rütbe idi. Devlet-i Aliyye'ye mâlen bedenen fevkalâde hidmetlerde bulunan asdika-yı bendegândan ba'zılarına tevcih olunurdu. Hacı Eyyûb Ăga'nın dahi müddet-i medîde bîna ve surre emânetleri ve ordu-yı hümayunlar hidmetleri gibi mesbûk olan fedâkârlı̆ğ semeresi olarak seksen yaşına kadar ömrü içinde şeref-yâb olabildiği nişân ile rütbesinin def'aten mahdumuna verilişi Sâdık Bey'in kadrini taz'if etmiş ise de zât-ı rütbenin kuvve-i nâmiyyesini tenkis eylemişdir. ${ }^{44}$

37 Klasik dönemde Osmanlı sarayında, başlıca muhafızlık ve teşrifatçılık işlerini gören önemli görevlerden biri iken zamanla görev tanımı değișmiştir. Son dönemde ise bir paye olarak verilmiștir. Bkz. Abdülkadir Özcan, "Kapıcı", TDVIA, http://www.islamansiklopedisi.info/dia/pdf/c24/c240217.pdf (erişim: 07.08.2015) ${ }^{38}$ BOA. HAT 1261/48853, 29 Z 1251 (16 Nisan 1836)

39 Istabl-ı Âmire, saray ahırları sorumluluğu yani Mirahurluk yerine kullanılmış bir terim olup II. Mahmud zamanında yeniden düzenlenmiștir. 1837 yılında mîrâhur unvanı kaldırılarak yerine Istabl- Âmire Müdürlüğü kurulmuş ve varlığını saltanatın sonuna kadar devam ettirmiștir. Mîrâhur veya Istabl-ı Âmire Müdürü unvanları bazen yüksek rütbeli pâye olarak da verilmiștir. Bkz. Abdülkadir Özcan, "Istabl", TDVIA, http://www.islamansiklopedisi.info/dia/pdf/c19/c190092.pdf (erişim: 07.08.2015)

40 Uluçay-Gökçen, Manisa Tarihi, s. 57; Uluçay, Ünlüler, s. 61

41 Mecidi Nişanı da denilen bu taltif aracı Osmanlı Devleti'nin batı tarzındaki ilk nişanıdır ve 1852 'de verilmeye başlanmıştır. En yükseği birinci olmak üzere 5 dereceye ayrılmıştır. Bkz. İbrahim Artuk, "Nişan", TDVIA, http://www.islamansiklopedisi.info/dia/pdf/c33/c330112.pdf erişim: 07.08.2015)

42 A. DVN. MHM. 34/62 00 R 1278 (Ekim-Kasım 1861)

43 BOA. A. DVN. MHM. 34/62 25 L 1277 (6 Mayıs 1861)

${ }^{44}$ Lûtfî Tarihi, C. 6-7-8, s. 1185 
Görüldüğü üzere Ahmed Lûtfî Efendi, bu tevcih ve taltifin, Sadık Bey'in kıymetini artırdığını ancak rütbenin kıymetini azalttığını belirtmektedir. Yazarın niçin bu kanaate sahip olduğunu söylemek şu anda mümkün değildir.

\section{V. Ölümü ve Serveti}

Mehmed Sadık Bey (1278) 1861 yılında Manisa'da ölmüş, Çeşnigir Camii haziresinde medfundur.45 Ancak Göktaşlı Mahallesi'ndeki konağında vefat ettiğini belirten Nagata ise ölüm tarihini eserinin bir yerinde 1862 olarak vermiștir. Kesin gününü tespit edememekle birlikte 1861 yllının sonunda vefat ettiği muhakkaktır. ${ }^{46}$

Sadık Bey'in ailenin servet yönetiminde etkili olduğu söylenebilir. Aile büyüklerinin borçlarını ödeme işi genellikle kendisine havale edilmiştir. Örneğin Babası Hacı Eyüp Ağa'nın bir sarrafa olan borcunun oğlu tarafından ödenmesi istenmektedir. ${ }^{47}$ Aynı şekilde amcası Yakup Paşa'nın ölümünü müteakip bir alacaklısına olan borcunun da Sadık Bey tarafından ödenmesi istenmiştir. ${ }^{48}$ Mehmed Sadık Bey'in bu özelliği muhtemelen ya idarecilik vasfından yahut aile reisi olmasından kaynaklanmaktadır.

Mehmed Sadık Bey'in terekesi, servetini açıkça ortaya koymaktadır. Terekenin toplam değeri $3.660 .297,5$ kuruş olup 1.741.665 kuruşluk borcu düşüldükten sonra geriye 1.918 .632 kuruş kalmıştır. ${ }^{49}$ Nagata, Karaosmanoğullarının önde gelenleri arasında yaptığı bir değerlendirmede Sadık Bey'in servetinin hem alım gücü hem de rakamsal değer olarak ilk sıralarda geldiğini belirtmektedir..$^{50}$

Sadık Bey'in serveti zevceleri ve çocukları arasında paylaştırılmıştır. Buna göre en büyük hisse tek oğlu Mehmed Arif Bey'e düşmüştür. 843.776 kuruşluk bu verasetten sonra kızları Cemile ve Hatice Hanımlardan her birisi 421.887 kuruş; zevcelerinden Ayşe Hanım 80.299 kuruş, diğer zevceleri Canfeza ve Aşk-ı Niyaz Kadınlardan her birisi de 80.359 kuruş değerindeki servetlerin sahibi olmuşlardır.

Sadık Bey'in sahip olduğu servet çok çeşitli kalemlerden oluşmakta ve sadece Manisa ile sınırlı kalmamaktadır. Mehmet Sadık

\footnotetext{
45 Uluçay, Ünlüler, s. 61; her ne kadar Uluçay, kabrinin Çeşnigir Camii'nde bulunduğunu söylese de șu anda bu caminin bir haziresi olmamakla birlikte, benzer şekildeki hazirelerle birlikte bazı belediye bașkanlarının imar faaliyetleri çerçevesinde dağıtıldığı bilinmektedir.

46 Nagata, a.g.e. s. 56; 1861 için Bkz. BOA. C. DH. 130/6465 9 C 1278 (12 Aralık 1861); A. MKT. MVL. 137/75 13 C 1278 (16 Aralık 1861)

47 BOA. A. MKT. 54/73 22 Za 1262 (11 Kasim 1846)

48 BOA. A. MKT. UM. 412/71 8 Z 1276 (27 Haziran 1860)

49316 numaralı MȘS

50 Nagata, a.g.e., s. 166
}

300 | Celal Bayar Üniversitesi Sosyal Bilimler Dergisi - Cilt: 13, Sayı: 3, Eylül 2015 
Bey'in emlaki Manisa'da şu bölgelerde bulunmaktadır: Manisa şehir merkezi, Koldere, Mütevelli, Çavuş (Muhtemelen Çavuşoğlu), Birunören, Karaağaçll, Tatar, Çobanisa, Tokat (Çungara), Sinirli, Saruhanlı, Belen, Marmara, Ahmetli, Sart, Kafirboz, Palamud, Dönmez (Dönmezli), Selimşahlar, Kumtepe, Keçili, Karaoğlanl, Mihaili, Geri ve Yayaköy. Ayrıca Nif (Kemalpaşa/İzmir), Armutlu, Parsa, Ulucak, Hacılar, gibi bugün İzmir'e bağlı yerleşim birimlerinde de malları vardır. Bunların yanı sıra İzmir'de çeşitli dükkânlar ile pek çok Rumhane ve bir de Frenkhane'nin yarı hissesine sahip olduğu görülmektedir.

Tereke üzerinden anlaşıldığı kadarıyla emlakin çeşitliliği şu şekildedir: Konaklar, harem daireleri, çiftlikler, tarla, zeytinlik, dutluk, bahçe, arsa, değirmen, menzil, han, hamam, Rumhane, Frenkhane, şaraphane, kahvehane, v.s dükkânlar.

Bunlardan başka çeşitli hayvanat, nakit para ve çok çeşitli eşyalar da Sadık Bey'in servetine dâhildir.

Mehmed Sadık Bey'in servetinin muazzam miktarda olduğunu söylemek mümkünse de bunun kendinden sonra devam etmediği görülmektedir. Bu konuda da Ahmed Lûtfî Efendi eserinde Sadık Bey'in ölümünden bahsettiği bölümde şu ifadeleri kullanmıștır:

Aydın ve havâlisi erkânından meşhur Kara Osman-zâdeler'den Saruhan Sancağı Mutasarrıfı Hacı Eyüb Ağa-zade Sâdık Bey vefat eyledi. Mîr-i mümâileyhin fevtiyle Kara Osman familyasının avâze-i şöhret ve ma'muriyyeti zevâle erdi. Sâdık Bey'in mahdumu pederinden intikâl eden bunca servet ve sâmânı az vakit zarfinda savurup, telef ederek, kendisi dahi genç-iken vefât etmişdir. 51

Gerçekten de Sadık Bey'in oğlu Mehmed Arif Bey'in bir hayli borcu vardır ve bu borçlarından dolayı bazı mülklerini elden çıkarmak zorunda kalmıştır. ${ }^{52}$

\section{VI. İktisadi İlişkileri}

Karaosmanoğlu Mehmed Sadık Bey'in yöneticiliğinin yanı sıra, sahip olduğu mal varlığı üzerinden yoğun bir ticari faaliyet içinde olduğu söylenebilir. Ancak burada dikkati çeken başlıca husus, bu ilişkilerin ağırlıklı olarak Manisa ve İzmir'deki Rum ahali ile Sadık Bey arasında gerçekleşmesidir. Nagata'nın eserinde dile getirip hayli örnek verdiği şekilde, Karaosmanoğlu ailesinin Manisa'daki zirai ve ticari faaliyetlerinde başrolde genellikle Rumlar bulunmaktadır. 18. yüzyılın sonlarından itibaren ailenin çiftliklerinde çalışanlar ve

\footnotetext{
51 Vak'anüvis Ahmed Lûtfî Efendi Tarihi, C. X, Haz. Münir Aktepe, TTK Ankara 1988, s. $45-46$

52 Ferhat Berber, II. Abdülhamid'e Satılan Bir Çiftliğin Hikayesi ve Düşündürdükleri”, Hacettepe Üniversitesi Türkiyat Araştırmaları Dergisi, S. 202014 Bahar, ss. 27-43
} 


\section{Ferhat Berber}

kâhyaları çoğunlukla Rumlardan oluşmuş ve bunlar zamanla zenginleşmişlerdir. ${ }^{53}$

Sadık Bey'in bu durumu devam ettirdiği terekesinden anlaşılmaktadır. Mülkü olan dükkân v.b. ticari işletmeler çoğunlukla Rum ahaliden kimseler tarafından kullanılmaktadır. Ayrıca ölümünden üç yıl sonra, varislerin talebi üzerine Sadık Bey'in hayatta iken tahsil edemediği toplam 82.470,5 kuruşluk alacağı, 162 kişi üzerinde olup bunun 133'ü Rum'dur. ${ }^{54}$ Yine İzmir'deki Rumhanelerinin varlı̆̆ da bu yönde yorumlanabilir.

\section{Sonuç}

Karaosmanoğlu ailesi, diğer âyân aileleri gibi II. Mahmud'un saltanatında büyük güç kaybetmiș, Tanzimat döneminde de taşra idaresindeki etkileri azalarak bitmiştir. Ancak Mehmed Sadık Bey, yerel idareciliğin âyânlıktan memuriyete doğru evrildiği süreç içinde müstesna bir örnektir.

1842-1861 yılları arasındaki on dokuz sene zarfinda dört kez Saruhan Kaymakamlığı görevine gelmiş toplamda dokuz yıla yakın bu vazifeyi icra etmiştir. Döneminde Saruhan Sancağı'nda çok büyük atılımlar yapıldığına dair herhangi bir işaret olmamakla birlikte, Tanzimat reformları çerçevesinde bu reformlara karşı herhangi bir büyük rahatsızlık da göze çarpmamaktadır. Anlaşıldığı kadarıyla merkezi idare yeni teşkilatlanma sürecinde bölgeyi kontrol edebilecek bir yöneticiye ihtiyaç duyduğunda ilk akla gelen isim Sadık Bey olmuştur. Buna mukabil Sadık Bey de görevden kaçmamıș zaten fiilen hep rol aldığı bölgenin idaresinde, hukuken de kontrolü eline almıştır. Yani devletin merkezileşme ve modernleşme sürecinde ortadan kaldırılmaya çalıștığı eski unsurlarla zaman zaman işbirliği yapması, her iki tarafında işine gelmiștir. İdare-i maslahat denilebilecek bir yönetim tarzı ile Sadık Bey, modern idareci kimliği altında bölgedeki menfaatlerini eski usule benzer şekilde devam ettirmiştir.

Bunun yanı sıra ailenin yükseliş döneminde emek gücüne dayandığı Rum tebaa ile ilişkileri yine devam etmiştir. Sadık Bey ailenin başı olarak, bu unsurun artık derebeyi değil, ortak çalıștığı bir eşraf haline gelmiştir. Buna ilaveten kaymakamlık vazifesi de mevcut şartların devamını sağlamada muhakkak ki büyük öneme sahip olmuştur.

\footnotetext{
53 Nagata, a.g.e., Yazar eserin çeşitli bölümlerinde bu konuda pek çok örnek vermektedir.

54320 numaralı MȘS
}

302 | Celal Bayar Üniversitesi Sosyal Bilimler Dergisi - Cilt: 13, Sayı: 3, Eylül 2015 


\section{BAŞBAKANLIK OSMANLI ARȘIVİ \\ KAYNAKLAR}

A. DVN. 122/84; A. DVN. MHM. 34/62; A. DVN. MHM. 34/62; A. MKT. 133/3; A. MKT. 16/100; A. MKT. 54/73; A. MKT. 84/4; A. MKT. 87/20; A.MKT. 185/61; A.MKT. 12/24; A.MKT. 78/27; A.MKT. 84/94-A; A.MKT. 94/16; A. MKT. MVL. 137/75; A. MKT. MVL. 54/71; A. MKT. MVL. 70/28; A. MKT. MVL. 81/30; A. MKT. MVL. 86/76; A. MKT. MVL. 99/13; A. MKT. NZD. 126/67; A. MKT. NZD. 176/30; A. MKT. NZD. 223/40; A. MKT. NZD. 224/8; A. MKT. NZD. 260/71; A. MKT. NZD. 57/84; A. MKT. UM. 412/71; A. MKT. UM. 544/21; A. MKT. UM. 9/10; A. TŞF. 14/34; A. TŞF. 21/90; A. TŞF. 22/6; A. TŞF. 4/63; A.MKT. UM. 320/74; C. DH. 130/6465; HAT 1261/48853; İ. MVL. 321/13641; İ. MVL. 357/15660

\section{SERIYYE SÍCILLERI}

316 numaralı Manisa Şeriyye Sicili

320 numaralı Manisa Șeriyye Sicili

\section{ARASTIRMA ESERLER}

Ahmed Lûtfî Efendi (1999), Vak'anüvîs Ahmed Lûtfî Efendi Tarihi, C. 6-7-8,Türkiye Ekonomik ve Toplumsal Tarih Vakfı-Yapı Kredi Yayınları, ed. Nuri Akbayar, İstanbul.

ARTUK İbrahim, "Nişan", TDVIA, http://www.islamansiklopedisi.info/dia/pdf/c33/c330112.pdf erişim: 07.08.2015)

BAYKARA, Tuncer (2000), Anadolu'nun Tarihi Coğrafyasına Giriş I Anadolu'nun İdari Taksimatı, Türk Kültürünü Araştırma Enstitüsü, Ankara.

BERBER, Ferhat (2014), II. Abdülhamid'e Satılan Bir Çiftliğin Hikâyesi ve Düşündürdükleri", Hacettepe Üniversitesi Türkiyat Araştırmaları Dergisi, S. 20 Bahar, ss. 27-43.

BERBER, Ferhat (2010), Imparatorluktan Cumhuriyete Manisa ve Göçler (1860-1960), Hacettepe Üniversitesi SBE Yayınlanmamış Doktora Tezi, Ankara.

BEYDILLLI, Kemal, "Mustafa Reșid Pașa", TDVIA, http://www.islamansiklopedisi.info/dia/pdf/c31/c310228.pdf (erişim: 13.08.2015)

BİLGİ, Nejdet (1999), "Tanzimat'ın Öncesi ve Sonrasında Saruhan Sancağı'nda Nüfus", Prof. Dr. İsmail Aka Armağanı, Yay. Haz. N. Bilgi, M. Ersan v.d., İzmir, ss. 249-290.

CCADIRCI, Musa, Tanzimat Döneminde Anadolu Kentlerinin Sosyal ve Ekonomik Yapısl, TTK Ankara, 1997

ÇADIRCI, Musa (2007), Tanzimat Sürecinde Türkiye Ülke Yönetimi, İmge Kitabevi, Ankara. 
EMECEN $\quad$ Feridun, "Manisa", TDVIA, http://www.islamansiklopedisi.info/dia/pdf/c27/c270394.pdf (erişim: 10.08.2015);

GÜRPINARLI Hilal Ortaç, "İzmir ve Saruhan Sancaklarındaki Âşar Yolsuzluğu, Kıtlık ve İdari Sonuçları”, TiD, C. XVII S. 1 Temmuz 2002, ss. 13-38

NAGATA Yuzo, "Karaosmanoğulları", TDVIA, http://www.islamansiklopedisi.info/dia/pdf/c24/c240290.pdf (erişim: 09.08.2015)

NAGATA, Yuzo (1997), Tarihte Âyânlar Karaosmanoğulları Üzerinde Bir Inceleme, TTK, Ankara .

ORTAC, Hilal (1996), Tanzimattan Birinci Meșrutiyete Manisa, Ege Üniversitesi, SBE, Tarih ABD, Yayınlanmamış Doktora Tezi, İzmir.

ÖZCAN Abdülkadir, "Istabl", TDVIA, http://www.islamansiklopedisi.info/dia/pdf/c19/c190092.pdf (erişim: 07.08.2015)

ÖZCAN Abdülkadir, "Kapıcı", TDVIA, http://www.islamansiklopedisi.info/dia/pdf/c24/c240217.pdf (erişim: 07.08.2015)

ÖZKAYA Yücel, "Kaymakam", TDVIA, http://www.islamansiklopedisi.info/dia/pdf/c25/c250059.pdf (erişim: 06.08.2015)

PAKALIN, Mehmet Zeki (2008), Sicill-i Osmanî Zeyli (19 cilt), Haz. Heyet, TTK, Ankara.

SÜREYYA, Mehmed (1996), Sicill-i Osmani (6 cilt), Haz. Nuri Akbayar, Tarih Vakfı Yurt Yayınları, İstanbul.

ULUÇAY, Çağatay-İbrahim Gökçen (1939), Manisa Tarihi, Manisa Halkevi Yayını, Resimli Ay Matbaası, İstanbul.

ULUÇAY, M. Çağatay (1946), Manisa Ünlüleri, Manisa Lisesi Yayını, Manisa.

Vak’anüvis Ahmed Lûtfî Efendi Tarihi (1988), C. X, Haz. Münir Aktepe, TTK, Ankara. 